\title{
Correction to: Sexual violence in older adults: a Belgian prevalence study
}

\author{
Anne Nobels ${ }^{1,2^{*}}$, Adina Cismaru-Inescu ${ }^{3,4+}$, Laurent Nisen ${ }^{3}$, Bastien Hahaut ${ }^{3}$, Marie Beaulieu ${ }^{5}$, \\ Gilbert Lemmens ${ }^{2,6}$, Stéphane Adam ${ }^{4}$, Evelyn Schapansky ${ }^{7}$, Christophe Vandeviver ${ }^{7,8 \ddagger}$ and Ines Keygnaert ${ }^{1}$
}

\section{Correction to: BMC Geriatr 21, 601 (2021) \\ https://doi.org/10.1186/s12877-021-02485-3}

After publication of this article [1], the authors reported that Christophe Vandeviver was not indicated as shared last author. Ines Keygnaert and Christophe Vandeviver are shared last authors.

The original article [1] has been updated.

\begin{abstract}
Author details
${ }^{1}$ International Centre for Reproductive Health, Department of Public Health and Primary Care, Ghent University, Ghent, Belgium. ${ }^{2}$ Department of Psychiatry, Ghent University Hospital, Ghent, Belgium. ${ }^{3}$ CARE-ESPRIst, Études et évaluations, University of Liège, Liège, Belgium. ${ }^{4}$ Psychology of Aging Unit, University of Liège, Liège, Belgium. ${ }^{5}$ School of Social Work and Research Centre on Aging, University of Sherbrooke, Quebec, Canada. ${ }^{6}$ Department of Head and Skin - Psychiatry and Medical Psychology, Ghent University, Ghent, Belgium. ${ }^{7}$ Department of Criminology, Criminal Law and Social Law, Ghent University, Ghent, Belgium. ${ }^{8}$ Research Foundation_Flanders (FWO), Brussels, Belgium.
\end{abstract}

Published online: 25 January 2022

\section{Reference}

1. Nobels A, Cismaru-Inescu A, Nisen L, et al. Sexual violence in older adults: a Belgian prevalence study. BMC Geriatr. 2021;21:601. https://doi.org/10. 1186/s12877-021-02485-3.

The original article can be found online at https://doi.org/10.1186/s12877021-02485-3.

*Correspondence: anne.nobels@uzgent.be ${ }^{+}$Adina Cismaru-Inescu is shared first author.

${ }^{\ddagger}$ Christophe Vandeviver is shared last author.

2 Department of Psychiatry, Ghent University Hospital, Ghent, Belgium

Full list of author information is available at the end of the article

(c) The Author(s) 2022. Open Access This article is licensed under a Creative Commons Attribution 4.0 International License, which permits use, sharing, adaptation, distribution and reproduction in any medium or format, as long as you give appropriate credit to the original author(s) and the source, provide a link to the Creative Commons licence, and indicate if changes were made. The images or other third party material in this article are included in the article's Creative Commons licence, unless indicated otherwise in a credit line to the material. If material is not included in the article's Creative Commons licence and your intended use is not permitted by statutory regulation or exceeds the permitted use, you will need to obtain permission directly from the copyright holder. To view a copy of this licence, visit http://creativecommons.org/licenses/by/4.0/. The Creative Commons Public Domain Dedication waiver (http://creativeco mmons.org/publicdomain/zero/1.0/) applies to the data made available in this article, unless otherwise stated in a credit line to the data. 